\title{
Cloning and High Level Production of Engineered Synthetic Cationic Antimicrobial Peptide using Methanol Inducible Pichia pastoris GS115
}

\author{
Seetha Ram Kotra ${ }^{1}$, K. Sobha ${ }^{2}$, V. Viharika ${ }^{3}$, A. Pavan Kumar ${ }^{2}$, P. Vengala Rao ${ }^{4}$, M. \\ Mary Vijaya Kumari ${ }^{5}$, Kona Prasad ${ }^{2}$, G. Ravi Teja ${ }^{2}$, K. V. Rajesh ${ }^{6}$ and JB Peravali ${ }^{6}$ \\ ${ }^{1}$ Department of Biotechnology, Acharya Nagarjuna University, \\ Guntur - 522510, India \\ ${ }^{2}$ Department of Biotechnology, R.V.R.\& J.C. College of Engineering, \\ Guntur - 522019, India \\ ${ }^{3}$ Department of Biology, Bharathi Junior College, Chirala - 523155, India \\ ${ }^{4}$ Department of Biotechnology, Alagappa University, Karaikudi-630003, India \\ ${ }^{5}$ Department of Microbiology, M.V.R. P.G. College, Gajuwaka-530026, India \\ ${ }^{6}$ Department of Biotechnology, Bapatla Engineering College, \\ Bapatla - 522101, India
}

Corresponding author: JB Peravali. E-mail: jbperavali@gmail.com;

$+919491475860$

\begin{abstract}
Engineered synthetic cationic antimicrobial peptides are the potential alternative drugs to existing antibiotics. In the present study, a novel attempt for the intracellular production of engineered synthetic cationic antimicrobial peptide (escAMP) using Pichia pastoris was studied. The engineered synthetic cationic antimicrobial peptide gene was synthesized using overlapping PCR. An entirokinase and hydroxylamine hydrochloride cleavage sites are incorporated at $N$ - and $C$-terminal end of escAMP respectively for easy purification. Later the gene was inserted into the MCS region of pPICZ-B vector. The synthetic peptide under the AOXI promoter was integrated into the Pichia pastoris GS115 genome and the recombinant clones were screened by using antibiotic resistance. Expression profiles of recombinant peptide were done using glycerol and methanol based synthetic medium and analysed on $18 \%$ Tricine-SDS-PAGE. Purification of the expressed peptide was done after cell disruption (10 cycles on time, 10 cycles off time and 10 min of total time) using $6 X$ histidine tag followed by enzymatic cleavage. In this study, $67 \mathrm{gm}$ of dry cell weight/L and $580 \mathrm{mg} / \mathrm{L}$ of purified escAMP was produced. The purified peptide is analysed for its anti microbial activity against different Gram positive and Gram negative microbes. For the first time smallest engineered synthetic cationic peptide was designed, cloned and expressed from methanol inducible Pichia pastoris GS115 and production ranges are encouraging.
\end{abstract}

Keywords: pPICZ-B, Pichia pastoris, AOX1 promoter, $18 \%$ Tricine-SDS-PAGE, $6 X$ histidine tag, enzymatic cleavage

\section{Introduction}

Multi-cellular organisms consist of several mechanisms to protect from the infectious microbes. On the other hand antibiotics are in the market to control the various infectious 
diseases. The increased availability due to bulk production of various antibiotics has led to widespread and improper use, leads to the several side effects viz., fever, seizures, amnesia, nervous disorders, etc. As an alternative, novel potential source of antimicrobial drugs are being sought. These peptide antibiotics are produced by various species of bacteria, insects, plants and vertebrates [1]. In the present day scenario, antimicrobial drugs are the upcoming therapeutic molecules to the existing antibiotics. The production of these peptides has a good scope in current antibiotic research [2].

In general, the antimicrobial peptides consists of 10-50 amino acids and work against a wide range of pathogenic organisms in different ways by interacting and disturbing the bacterial cell wall, cell membrane and at various intracellular parts directly or indirectly [3]. Native production was not up to the industrial needs and also cost of purification is also high. Hence, production using recombinant hosts is encouraging. The mostly used host is Escherichia coli because of its well understood genetic map and cost effective production [4, $5,6]$. But problems like fast proteolysis, poor absorption, cost of the drug and toxic nature are the major hurdles $[7,8,9,10]$. To avoid such hindrance an engineered peptide was designed and cloned in eukaryotic host results the production of peptide devoid of side effects [11]. Eukaryotic host like Pichia pastoris is the prominent host for the production of recombinant therapeutics $[12,13]$.

The present work has been carried out to design the engineered cationic antimicrobial peptide using in-silico tools followed by cloning and expression using eukaryotic system Pichia pastoris. Purification was carried out using $6 \mathrm{X}$ histidine tag and activity analysis of the peptide was studied using different Gram positive and Gram negative pathogenic microorganisms.

\section{Materials \& methods}

\subsection{Strains and media}

E. coli DH5 $\alpha$ was used as maintenance host and was procured from MTCC, Chandigarh. Recombinant transformants were selected on solidified Luria-Bertani plates supplemented with $25 \mu \mathrm{g}$ of antibiotic (zeocin) per $\mathrm{mL}$.

$P$. pastoris GS115 used as expression host was purchased from Invitrogen and was propagated on yeast extract peptone dextrose (YEPD) agar plates containing yeast extract $10 \mathrm{~g} / \mathrm{L}$, peptone $-20 \mathrm{~g} / \mathrm{L}$, dextrose $-20 \mathrm{~g} / \mathrm{L}$ and agar $-20 \mathrm{~g} / \mathrm{L}$.

Recombinant $P$. pastoris strains were selected on regeneration dextrose medium (RDB) agar plates containing yeast nitrogen base $-13.4 \mathrm{~g} / \mathrm{L}$, dextrose $-20 \mathrm{~g} / \mathrm{L}, 1 \mathrm{M}$ sorbitol, amino acid mix (L-glutamic acid, L-methionine, L-lysine, L-leucine and L-isolucine) - $50 \mathrm{mg} / \mathrm{L}$, biotin $-400 \mu \mathrm{g} / \mathrm{L}$ and agar $-20 \mathrm{~g} / \mathrm{L}$.

For growth and induction, buffered methanol-complex medium (BMMY) or buffered glycerol-complex medium (BMGY) media (yeast extract $-10 \mathrm{~g} / \mathrm{L}$, peptone $-20 \mathrm{~g} / \mathrm{L}$, yeast nitrogen base $-13.4 \mathrm{~g} / \mathrm{L}, 100 \mathrm{mM}$ potassium phosphate ( $\mathrm{pH} 6.0$ ), biotin $-400 \mu \mathrm{g} / \mathrm{L}$, glycerol $-10 \mathrm{~mL}$ or methanol $-5 \mathrm{~mL}$ ) were used.

\subsection{Computational tools used}

The desired synthetic cationic antimicrobial peptide was designed by using in-silico tools, i.e., hierarchical neural network (HNN), antimicrobial peptide database (AMPDB) and protparam (PP). 


\subsection{PCR amplification}

The synthetic cationic antimicrobial peptide gene was engineered using over lapping PCR with the following primers (Sigma-Aldrich, Bangalore, India). Forward primer (72 mer) sequence was

CCGGAATTCATGGACGATGACGATAAGATGTGCCTTAAAGTCCGTATTTGGTTTA AAATGGAGGCGGAGGAC 3' and reverse primer $(77$ mer) sequence was 5' TGCTCTAGAGCCGTTCATCTTGAAGCAGATGCGCACCTTCAGGCACATGTCCTCC GCCTCCATTTTAAACCAAATAC 3'. Enterokinase $(E K)$ cleavage site is incorporated at 5' end of forward primer and hydroxylamine hydrochloride (Asn-Gly) cleavage site was incorporated at 5' end of reverse primer. The PCR reaction set up with an initial denaturation at $95{ }^{\circ} \mathrm{C}$ for $5 \mathrm{~min}$, followed by 25 cycles of $95{ }^{\circ} \mathrm{C}$ for $30 \mathrm{~s}, 60{ }^{\circ} \mathrm{C}$ for $45 \mathrm{sec}$ and $72{ }^{\circ} \mathrm{C}$ for 45 sec and a final extension at $72{ }^{\circ} \mathrm{C}$ for $10 \mathrm{~min}$. Later the amplified PCR product was purified using Gen Elute PCR clean-up kit (Qiagen) as per the manufacturer's instruction.

\subsection{Construction of recombinant vector}

All molecular cloning steps were performed as described in Sambrook et al., 1989 [14]. The purified PCR product was double digested with EcoRI and XbaI. The purified double digested PCR product was ligated to double digested pPICZ-B vector at 1:3 ratio. Later the ligation mixture was introduced into chemically competent $E$. coli $\mathrm{DH} 5 \alpha$ cells and the highest concentrations of zeocin resistant transformants were screened for the presence of synthetic cationic antimicrobial peptide gene. On the other hand, colony lysate PCR was done using gene specific primers and double digestion of recombinant vector is carried out to confirm the ligation, followed by DNA sequencing.

\subsection{Transformation to $P$. pastoris}

The recombinant plasmid escAMP/pPICZ-B was linearized using SacI and transformed to P. pastoris by electroporation using an electroporator at $2000 \mathrm{~V}$ with a $0.2 \mathrm{~cm}$ cuvette. After electroporation, immediately $1 \mathrm{~mL}$ of ice-cold $1 \mathrm{M}$ sorbitol was added to the cuvette and allowed for incubation for $1 \mathrm{hr}$ at $30{ }^{\circ} \mathrm{C}$. Later the cells were plated on RDB agar plates with different concentrations (ascending concentration) of zeocin and incubated at $30{ }^{\circ} \mathrm{C}$ for $2-3$ days until the colonies appeared. The genomic DNA was isolated from the recombinant transformants using Qiagen genomic DNA isolation kit and the integration of the gene was confirmed with gene specific primers.

\subsection{Expression of escAMP}

Clones of highest zeocin resistance was chosen and inoculated into baffled shake flask containing $25 \mathrm{~mL}$ BMGY and were grown at $30{ }^{\circ} \mathrm{C}$ for $18-24 \mathrm{hrs}$ until the culture $\mathrm{OD}_{600}$ reaches between 2-6. Later, cells were harvested by centrifugation at 2,000 X g for 5 minutes and resuspend in BMMY with methanol as an inducer. $100 \%$ methanol was added to a final concentration of $0.5 \%$ every 12 hours to maintain induction. To prevent glycosylation of escAMP, expression in another flask was carried out with $20 \mu \mathrm{g}$ tunicamycin/mL in the induction medium as described by Sebban-Kreuzer et al., 2006 [15]. Expression of escAMP was analyzed on a $18 \%$ Tricine-SDS-PAGE. After sonication, escAMP concentration was estimated by Lowry method [16]. 


\subsection{Purification of escAMP}

The engineered peptide containing an $\mathrm{C}$-terminal $6 \mathrm{X}$ His tag was expressed and purified using affinity chromatography with $\mathrm{Ni}^{2+}$ resin $\mathrm{In}$ order to purify the peptide, $800 \mathrm{mg}$ of wet cells were obtained from a freshly grown culture. The cells were harvested and centrifuged at $13,800 \mathrm{rpm}$ for $10 \mathrm{~min}$ at room temperature. Later the pellet was suspended in $12 \mathrm{~mL}$ of guanidinium lysis buffer containing $7 \mathrm{M}$ guanidine $\mathrm{HCl}, 22 \mathrm{mM}$ sodium phosphate, $510 \mathrm{mM}$ $\mathrm{NaCl}$ with pH 7.8 at $4^{\circ} \mathrm{C}$ for $1 \mathrm{hr}$. The cell lysate was again centrifuged at 13,800 rpm for 10 to $15 \mathrm{~min}$ at room temperature. A volume of $10 \mathrm{~mL}$ cell lysate was purified on a column containing $2 \mathrm{~mL}$ resin equilibrated with denaturing binding buffer, incubated for $45 \mathrm{~min}$ at room temperature with gentle hand shaking for several times. The column was washed with 6 $\mathrm{mL}$ of denaturing wash buffer and twice with $6 \mathrm{~mL}$ of native wash buffer. The bounded peptide was eluted with $5 \mathrm{~mL}$ of native elution buffer and analysed on $18 \%$ Tricine-SDSPAGE against standard protein marker.

After purification, escAMP was incubated in hydroxylamine cleavage buffer (2 M hydroxylamine hydrochloride, $0.2 \mathrm{M}$ Tris $\mathrm{HCl}, \mathrm{pH} 9.0$ ) for $4 \mathrm{hrs}$ at $45{ }^{0} \mathrm{C}$ followed by cleavage with entirokinase. The reaction was terminated by cooling the samples and adjusting the $\mathrm{pH}$ to acidic. After enzymatic cleavage the peptide samples was dialyzed twice with 10 $\mathrm{mM}$ Tri Hcl, pH 8.0 for $16 \mathrm{hrs}$ at $4{ }^{0} \mathrm{C}$ using $2.5 \mathrm{kDa}$ (initially) and $3.5 \mathrm{kDa}$ (finally) cutoff membranes and later dialyzed sample was loaded on Q Sepharose column matrix equilibrated with the same buffer. The bound peptides were eluted with a linear gradient of $\mathrm{NaCl}(0-1 \mathrm{M})$ in the same buffer. The elute containing escAMP were dialyzed against 100 volumes of 20 $\mathrm{mM}$ sodium acetate buffer, $\mathrm{pH} 4.5$ and passed through a SP-Sepharose column matrix. The bound escAMP was eluted using a linear gradient of $\mathrm{NaCl}(0-1 \mathrm{M})$ in the same buffer. The purity of the peptide was analyzed using $18 \%$ Tricine - SDS - PAGE.

\subsection{Antimicrobial activity assay}

The antibacterial activity of engineered recombinant synthetic cationic antimicrobial peptide was tested by well diffusion method using $E$. coli. On the other hand, minimum inhibitory concentration (MIC) of the purified and unpurified escAMP was determined against different Gram negative and Gram positive microbes viz., Klebsiella pneumoniae, Haemophilus influenza, Staphylococcus aureus, Micrococcus luteus and Bacillus subtilis by a liquid growth-inhibition assay [17].

\section{Results \& Discussion}

\subsection{Synthesis of escAMP}

The desired 102 bp length DNA was synthesized by using overlapping PCR. The result of the PCR methodologies was analyzed and confirmed the amplified product on $2 \%$ agarose gel against a $100 \mathrm{bp}$ DNA ladder. Further this gene is used as template to amplify the escAMP with a different set of primers containing restriction sites at 5' end and the desired product size of $120 \mathrm{bp}$ DNA is confirmed on $2 \%$ agarose (Figure 1). 


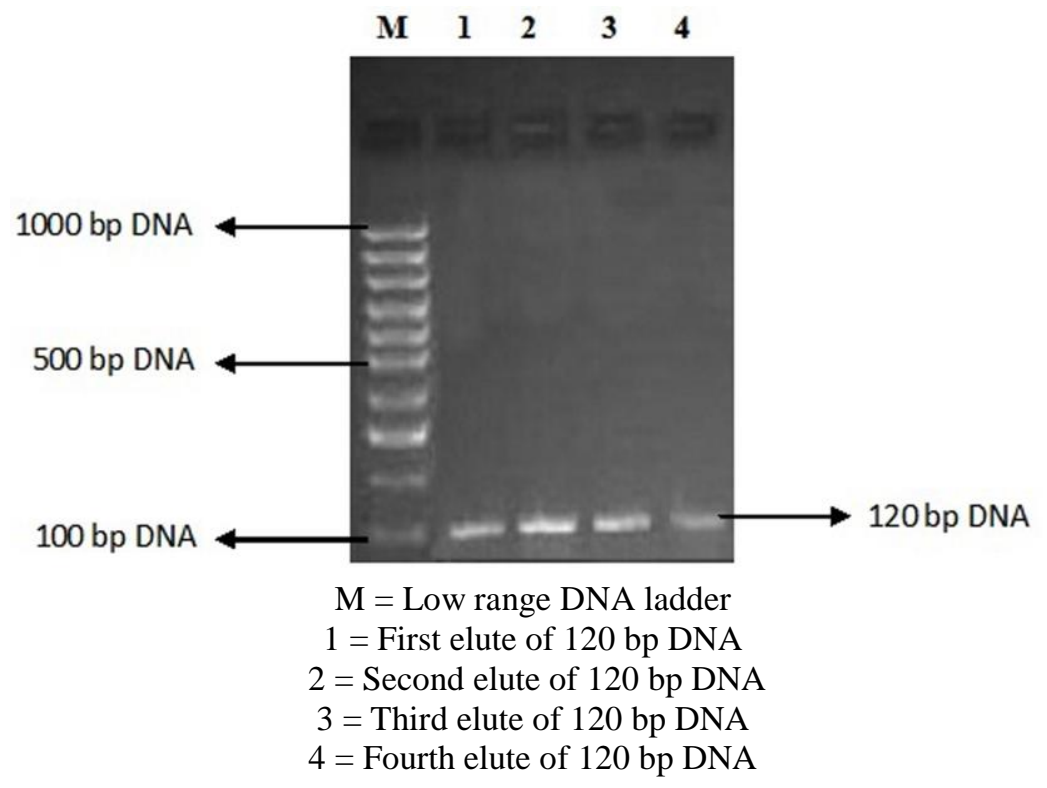

Figure 1. Analysis of PCR amplified engineered synthetic cationic antimicrobial peptide (escAMP) gene against 100 bp DNA ladder

\subsection{Construction of pPICZ-B-escAMP expression vector}

The double digested purified PCR product was cloned in pPICZ-B vector between EcoRI and $X b a \mathrm{I}$ sites using $\mathrm{T}_{4}$ DNA ligase. After PCR confirmation of the recombinant plasmid (pPICZ-B-escAMP) (Figure 2), electroporation was carried out into P. pastoris produced more than 30 colonies in highest zeocin concentration $100 \mu \mathrm{g} / \mathrm{mL}$ instead of normal concentration $25 \mu \mathrm{g} / \mathrm{mL}$.

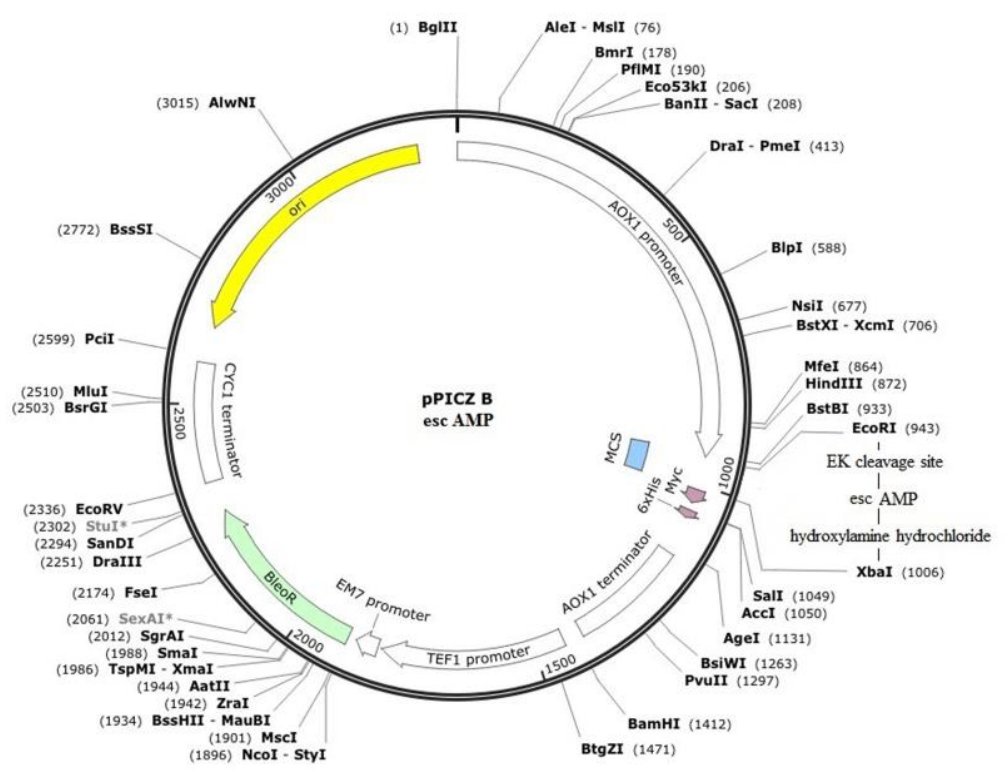

Figure 2. Schematic representation of the recombinant expression vector pPICZ-B -escAMP 
The recombinant clone was isolated and linearized with $\mathrm{SacI}$ and introduced into $P$. pastoris using electroporation. The recombinant Pichia pastoris transformants gave expected size (202 bp) of PCR product using gene specific reverse primer and vector specific forward primer (Figure 3 ) and followed by sequencing.

\section{5' GACTGGTTCCAATTGACAAGCTTTTGATTTTAACGACTTTTAACGACAACTTGAGAA GATCAAAAAACAACTAATTATTCGAAACGAGGAATTCATGGACGATGACGATAAGATG TGCCTTAAAGTCCGTATTTGGTTTAAAATGGAGGCGGAGGACATGTGCCTGAAGGTGC GCATCTGCTTCAAGAACGGCTCTAGAGCA 3'}

Figure 3. DNA sequencing of recombinant synthetic cationic antimicrobial peptide amplified using 5' AOX1 sequencing primer and gene specific reverse primer

\subsection{Expression of escAMP}

For the expression studies, methanol inducible Pichia pastoris GS115 was used. This expression system was chosen owing to its simplicity. As mentioned earlier all peptide expressions were analyzed by running on $18 \%$ Tricine-SDS-PAGE against standard protein marker and a very clear $6.1 \mathrm{kDa}$ band was identified against a low molecular weight protein ladder (Figure 4). The observed results in the present investigation were coincided with the similar expression patterns in E. coli.

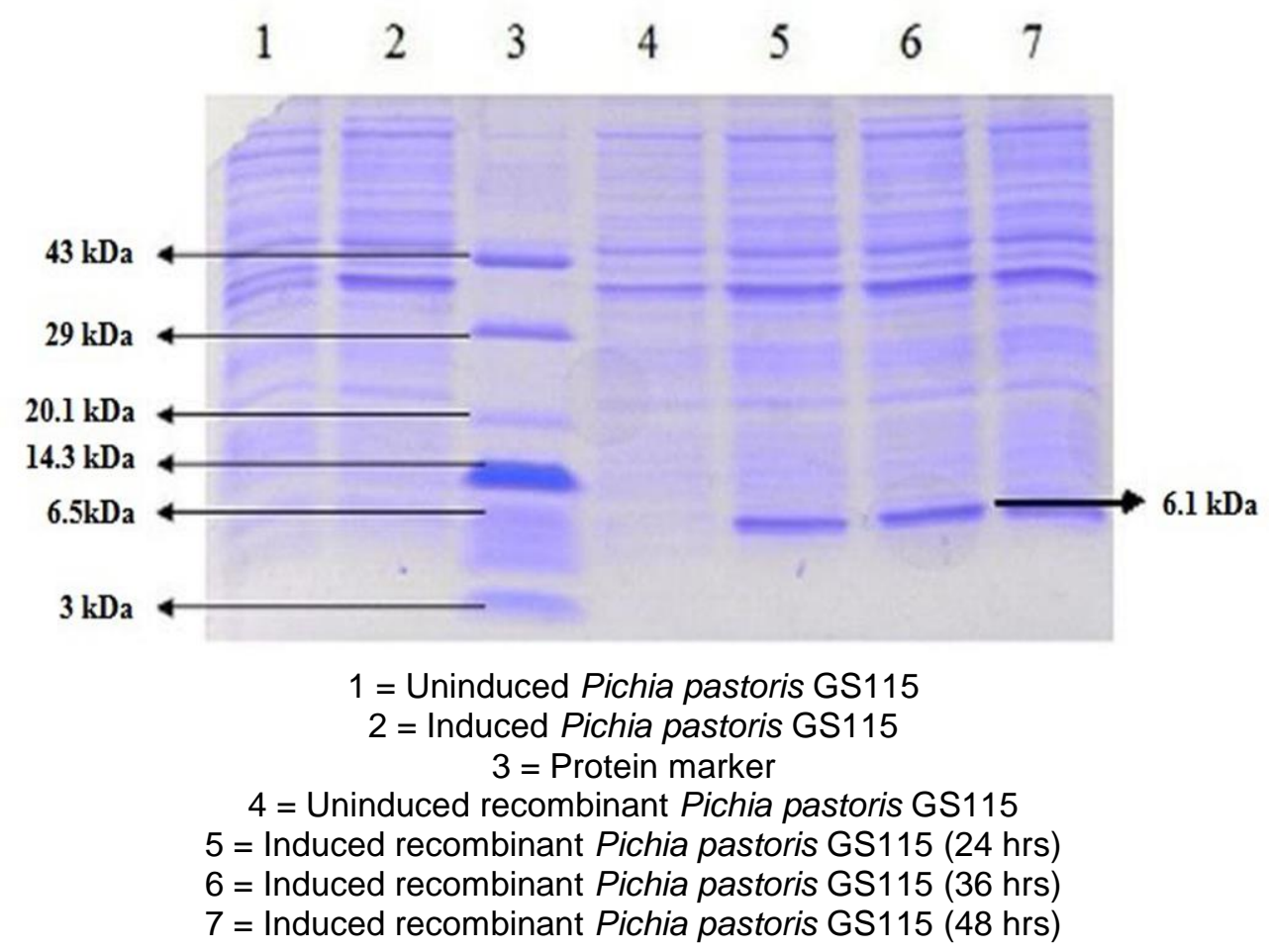

Figure 4. Tricine SDS PAGE analysis of engineered synthetic cationic antimicrobial peptide (escAMP) 


\subsection{Purification of the peptide}

Purification of the intracellular peptide was carried out using $6 \mathrm{X}$ histidine column by loading the supernatant after sonication followed by enzymatic cleavage. Tricine-SDSPAGE analysis of the purified sample showed single band slightly at $3 \mathrm{kDa}$, which is consistent with the molecular weight of escAMP and was also confirmed by western blot analysis. Upon quantification, $580 \mathrm{mg} / \mathrm{L}$ of purified peptide was achieved.

\subsection{Antimicrobial activity assay}

Antimicrobial assay was performed to determine the activity of the purified and unpurified escAMP. Figure 5 shows the zone of clearance around the treated well of different concentration of purified and unpurified samples, but no zone of clearance is observed around the control well.
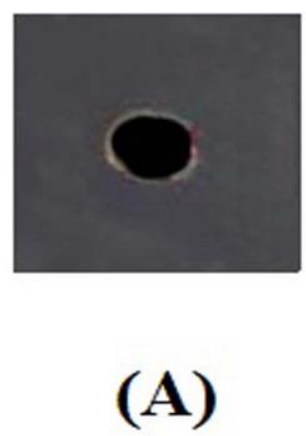

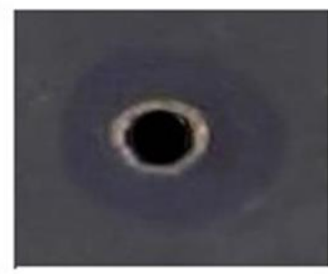

(B)

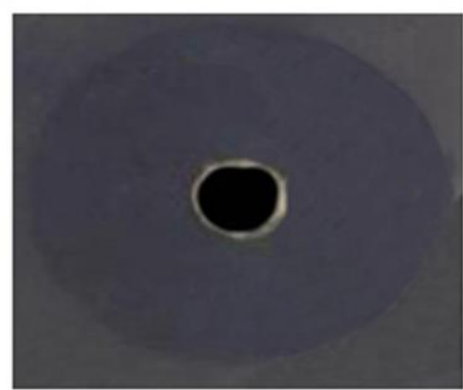

(C)
(A). $-\mathrm{Ve}(\mathrm{PBS})$,
(B) $25 \mu$ of unpurified escAMP,
(C) $4 \mu \mathrm{l}$ of purified escAMP

Figure 5. Antimicrobial activity of escAMP on E. coli

The MICs of the purified and unpurified escAMP against several microorganisms were shown in Table 1. These results demonstrated the recombinant peptides were functional and active after enzymatic cleavage.

\section{Table 1. Minimal inhibitory concentrations (MICs) of synthetic cationic peptide on Gram positive and Gram negative microorganisms}

\begin{tabular}{|c|c|c|}
\hline Microorganism & Unpurified peptide $(\mu \mathrm{g} / \mathrm{mL})^{\mathrm{a}}$ & Purified peptide $(\mu \mathrm{g} / \mathrm{mL})^{\mathrm{a}}$ \\
\hline Klebsiella pneumoniae & 25 & 4 \\
\hline Haemophilus influenzae & 20 & 3 \\
\hline Bacillus subtilis & 40 & 5 \\
\hline Micrococcus luteus & 30 & 4 \\
\hline Streptococcus aureus & 35 & 3 \\
\hline
\end{tabular}

${ }^{a}$ Results are \pm of two independent experiments

The effect of antimicrobial activity of different concentrations of escAMP on growth of pathogenic bacteria viz., Staphylococcus aureus and Pseudomonas aeruginosa was illustrated in Figure 6 (A) and (B). $25 \mu \mathrm{g} / \mathrm{mL}$ of unpurified escAMP is enough to inhibit the growth of Staphylococcus aureus and $20 \mu \mathrm{g} / \mathrm{mL}$ of unpurified escAMP shows the inhibition of Pseudomonas aeruginosa. These purified engineered synthetic cationic AMP does not exhibit 
any haemolytic activity even at the highest concentrations $(50 \mu \mathrm{g} / \mathrm{mL})$ over night, indicating the cationic antimicrobial peptide was devoid of toxic nature to RBC.

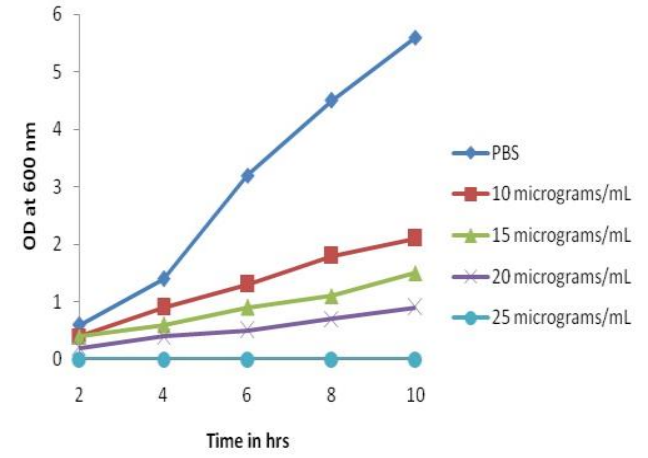

(A)

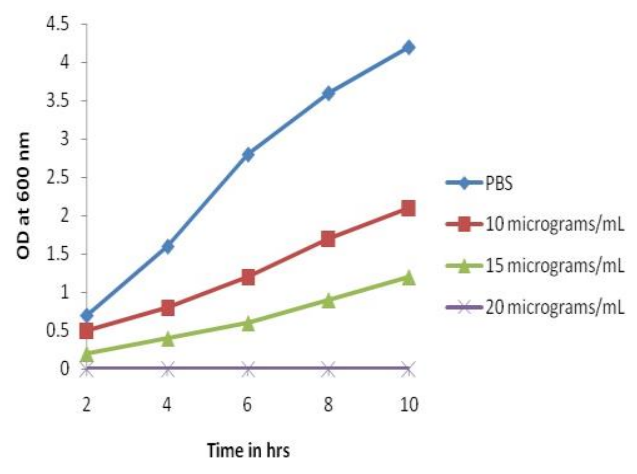

(B)

\section{Figure 6. (A). Concentrations of escAMP on propagation of Staphylococcus aureus; (B). Concentrations of escAMP on propagation of Pseudomonas aeruginosa}

\section{Conclusion}

The clinical applications of antimicrobial peptides in treatment of several infectious diseases have attracted the attention of researchers [18, 19]. Different antimicrobial peptides are produced using recombinant DNA technology [20, 21, 22]. Hypersensitivity and poor absorption are the drawbacks of major peptides [23, 24]. The present study focussed on engineered synthetic cationic antimicrobial peptide consists of 26 amino acids is a promising molecule synthesized using codon bias of Escherichia coli $[25,26]$. The production level of recombinant synthetic cationic antimicrobial peptide was relatively high when compared with PG-1 (1.1 mg/L) [27], active recombinant CM4 (1.4 mg/L) [28], recombinant PR-39 (1.9 $\mathrm{mg} / \mathrm{L})$ [27], cationic recombinant thanatin analog $(13.2 \mathrm{mg} / \mathrm{L})$ [29], cationic antimicrobial peptide lactoferricin $(60 \mathrm{mg} / \mathrm{L})$ [30], plectasin $(92 \mathrm{mg} / \mathrm{L})$ [31], mouse beta defensin-1 mature peptide (140 mg/L) [32], synthetic cationic antimicrobial peptide $(520 \mathrm{mg} / \mathrm{L}$ and $258 \mathrm{mg} / \mathrm{L})$ [33, 34], and slightly lower when compared to mature hBD4 (689 mg/L) [35]. Production levels are very far away from HBD5 (1.49 g/L) and HBD6 (1.57 g/L) [36].

In the present work, we constructed a recombinant system for the enhanced production of escAMP using the pPICZ-B expression vector. Still now no expression methods were reported using eukaryotic system and engineered peptides. For the first time Pichia pastoris was used for the production of small length engineered antimicrobial peptides.

\section{Acknowledgments}

The authors are grateful to Prof. J. Srinivasa Rao, Head of the Department of Chemical Engineering, Bapatla Engineering College, Bapatla, for his valuable suggestions and advices throughout the work. First author of this paper was acknowledging his personal thanks to Tanneru Bala Sundara Rao and Rajya Lakshmi for their moral support. 


\section{References}

[1] R. Bals, "Epithelial antimicrobial peptides in host defense against infection", Respir. Res., vol. 1, no. 3, (2000), pp. 141-150.

[2] D. Raventos, O. Taboureau, P. H. Mygind, J. D. Nielsen, C. P. Sonksen and H. H. Kristensen, "Improving on nature's defenses: Optimization \& high throughput screening of antimicrobial peptides", Comb. Chem High Throughput Screen, vol. 8, no. 3, (2005), pp. 219-233.

[3] R. M. Epand and H. J. Vogel, "Diversity of antimicrobial peptides and their mechanisms of action", Biochim. Biophys. Acta., vol. 1462, (1999), pp. 11-28.

[4] K. W. Miller, R. Schamber, Y. L. Chen and B. Ray, "Production of active chimeric pediocin AcH in Escherichia coli in the absence of processing and secretion genes from the Pediococcus pap operon", Appl. Environ. Microbiol., vol. 64, (1998), pp. 14-20.

[5] L. Zhang, T. Falla, M. Wu, S. Fidai, J. Burian, W. Kay and R. E. W. Hancock, "Determinants of recombinant production of antimicrobial cationic peptides and creation of peptide variants in bacteria", Biochem. Biophys. Res. Commun., vol. 247, (1998), pp. 674-680.

[6] J. H. Lee, J. H. Kim, S. W. Hwang, W. J. Lee, H. K. Yoon, H. S. Lee and S. S. Hong, "High level expression of antimicrobial peptide mediated by a fusion partner reinforcing formation of inclusion bodies", Biochem. Biophys. Res. Commun., vol. 277, no. 3, (2000), pp. 575-580.

[7] S. W. Hwang, J. H. Lee, H. B. Park, S. H. Pyo, J. E. So, H. S. Lee, S. S. Hong and J. H. Kim, “A simple method for the purification of an antimicrobial peptide in recombinant Escherichia coli. Mol. Biotechnol., vol. 18, (2001), pp. 193-198.

[8] I. Cipakova, E. Hostinova, J. Gasperik and V. Velebny, "High level expression and purification of a recombinant hBD-1 fused to LMM protein in Escherichia coli. Protein Expr. Purif., vol. 37, no. 1, (2004), pp. 207-212.

[9] S. H. Pyo, J. H. Lee, H. B. Park, J. S. Cho, H. R. Kim, B. H. Han and Y. S. Park, "Expression and purification of a recombinant buforin derivative from Escherichia coli. Process Biochem., vol. 39, no. 11, (2004), pp. $1731-1736$.

[10] X. C. Rao, S. Li, J. C. Hu, X. L. Jin, X. M. Hu, J. J. Huang, Z. J. Chen, J. M. Zhu and F. Q. Hu, “A novel carrier molecule for high-level expression of peptide antibiotics in Escherichia coli. Protein Expr. Purif., vol. 36, (2004), pp. 11-18.

[11] C. Gurramkonda and Polez, "Research Application of simple fed-batch technique to high-level secretory production of insulin precursor using Pichia pastoris with subsequent purification and conversion to human insulin. Microbial Cell Fact., vol. 9, (2010), pp. 31.

[12] A. L. Demain and P. Vaishnav, "Production of recombinant proteins by microbes and higher organisms", Biotechnol Adv., vol. 27, (2009), pp. 297-306.

[13] L. M. Damasceno and I. Pla, "An optimized fermentation process for high level production of a single-chain Fv antibody fragment in Pichia pastoris.", Protein Expression and Purif., vol. 37, no. 1, (2004), pp. 18-26.

[14] J. Sambrook and D. W. Russel, "Molecular Cloning: A Laboratory Manual", Cold Spring Harbor Laboratory Press, New York, NY, USA, (2009).

[15] C. S. Kreuzer, P. D. Beauclair, A. Berton and I. Crenon, "High level expression of nonglycosylated human pancreatic lipase-related protein 2 in Pichia pastoris", Protein Expr Purif., vol. 49, (2006), pp. 284-291.

[16] O. H. Lowry, N. J. Rosebrough, A. L. Farr and R. J. Randall, "Protein measurement with the Folin phenol reagent", J. Biol Chem., vol. 193, no. 1, (1951), pp. 265-275.

[17] M. H. Wu and R. E. W. Hancock, "Interaction of the cyclic antimicrobial cationic peptide bactenecin with the outer and cytoplasmic membrane”, J. Biol. Chem., vol. 274, (1999), pp. 29-35.

[18] F. Jacobsen, D. Mittler, T. Hirsch, A. Gerhards, M. Lehnhardt, B. Voss, H. U. Steinau and L. Steinstraesser, "Transient cutaneous adenoviral gene therapy with human host defense peptide hCAP-18/LL-37 is effective for the treatment of burn wound infections", Gene Ther., vol. 12, (2005), pp. 1494-1502.

[19] P. Kougias, H. Chai, P. H. Lin, Q. Yao, A. B. Lumsden and C. Chen, "Neutrophil antimicrobial peptide alpha-defensin causes endothelial dysfunction in porcine coronary arteries”, J. Vasc. Surg., vol. 43, (2006) pp. 357-363.

[20] A. Baroni, G. Donnarumma, I. Paoletti, I. L.-Cattani, K. Bifulco, M. A. Tufano and M. V. Carriero, "Antimicrobial human betadefensin- 2 stimulates migration, proliferation and tube formation of human umbilical vein endothelial cells", Peptides, vol. 30, (2006), pp. 267-272.

[21] L. F. Zhou, Q. P. Lin, B. C. Li, et al., "Expression and purification the antimicrobial peptide CM4 in Escherichia coli", Biotechnol. Lett., vol. 31, (2009), pp. 437-441.

[22] H. Chen, L. Fan, Z. Xu, X. Yin and P. Cen, "Efficient production of soluble human beta-defensin-3-4 fusion proteins in Escherichia coli cell-free system", Process Biochemistry, vol. 42, (2007), pp. 423-428. 
[23] Y. Yang, Z. Tian, D. Teng, J. Zhang, J. Wang and J. Wang, "High-level production of a candidacidal peptide lactoferrampin in Escherichia coli by fusion expression", Journal of Biotechnology, vol. 139, (2009), pp. $326-331$.

[24] L. Huang, C. B. Ching, R. Jiang and S. S. Leong, "Production of bioactive human betadefensin 5 and 6 in Escherichia coli by soluble fusion expression”, Protein Expr. Purif., vol. 61, (2008), pp. 168-174.

[25] Y. M. Shlyapnikov, Y. A. Andreev, S. A. Kozlov, A. A. Vassilevski and E. V. Grishin, "Bacterial production of latarcin 2a, a potent antimicrobial peptide from spider venom", Protein Expr. Purif., vol. 60, (2008), pp. 89-95.

[26] B. Srinivasulu, R. Syvitski, J. K. Seo, N. R. Mattatall, L. C. Knickle and S. E. Douglas, "Expression purification and structural characterization of recombinant hepcidin, an antimicrobial peptide identified in Japanese flounder, Paralichthys olivaceus", Protein Expr. Purif., vol. 61, (2008), pp. 36-44.

[27] F. Fan, Y. Wu and J. Liu, "Expression and purification of two different antimicrobial peptides, PR-39 and Protegrin-1 in Escherichia coli", Protein Expression and Purification, vol. 73, (2010), pp. 147-151.

[28] L. Zhou, Q. Lin, B. Li, N. Li and S. Zhang, "Expression and purification the antimicrobial peptide CM4 in Escherichia coli”, Biotechnol Lett., vol. 31, (2009), pp. 437-441.

[29] G. Q. Wu, L. X. Li, J. X. Ding, L. Z. Wen and Z. L. Shen, "High level expression and novel purification strategy of recombinant thanatin analog in Escherichia coli", Curr Microbiol., vol. 57, (2008), pp. 95-101.

[30] H. -K. Kim, D. -S. Chun, J. -S. Kim, C. -H. Yun, J. -H. Lee, S. -K. Hong and D. -K. Kang, "Expression of the cationic antimicrobial peptide lactoferricin fused with the anionic peptide in Escherichia coli", Appl Microbiol Biotechnol., vol. 72, (2006), pp. 330-338.

[31] X. -L. Jing, X. -G. Luo, W. -J. Tian, L. -H. Lv, Y. Jiang, N. Wang and T. -C. Zhang, "High-Level Expression of the Antimicrobial Peptide Plectasin in Escherichia col”, Curr Microbiol., vol. 61, (2010), pp. 197-202.

[32] Y. Wang, Y. Jiang, T. Gong, X. Cui, W. Li, Y. Feng, B. Wang, Z. Jiang and M. Li, "High level expression and novel antifungal activity of mouse beta defensin-1 mature peptide in Escherichia coli", Appl Biochem Biotechnol., vol. 160, (2010), pp. 213-221.

[33] J. B. Peravali, S. R. Kotra, G. R. Teja, P. Nelavalli, K. Prasad, A. Kumar, K. V. Rajesh, K. Sobha, R. Nelson and K. K. Pulicherla, "Molecular cloning, expression and invitro analysis of soluble cationic synthetic antimicrobial peptide from salt inducible Escherichia coli GJ1158. J. BioSci. Biotech., vol. 2, no. 3, (2013), pp. 181-188.

[34] J. B. Peravali, S. R. Kotra, S. K. Suleyman, T. C. Venkateswarlu, K. V. Rajesh, K. Sobha and K. K. Pulicherla, "Fermentative Production of Engineered Cationic Antimicrobial Peptide from Economically Feasible Bacterial Host E. coli. GJ1158”, International Journal of Bio-Science and Bio-Technology, vol. 5, no. 5 , (2013), pp. $211-222$.

[35] Z. Xu, Z. Zhong, L. Huang, L. Peng, F. Wang and P. Cen, "High level production of bioactive human betadefensin-4 in Escherichia coli by soluble fusion expression”, Appl Microbiol Biotechnol., vol. 72, (2006), pp. 471-479.

[36] L. Huang, C. B. Ching, R. Jiang and S. S. J. Leong, "Production of bioactive human beta-defensin 5 and 6 in Escherichia coli by soluble fusion expression", Protein Expression and Purification, vol. 61, (2008), pp. 168174. 